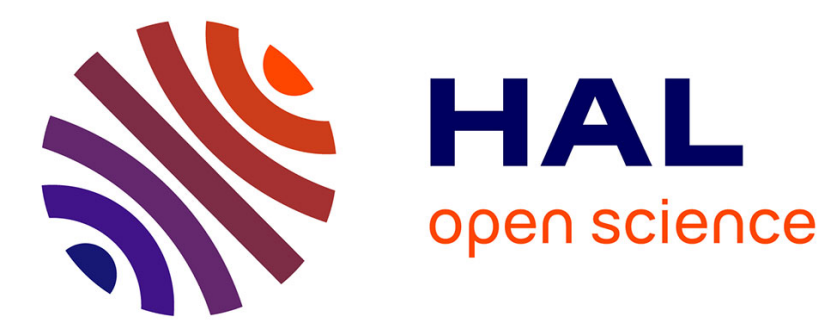

\title{
Relative chronology of Palaeolithic drawings of the Great Ceiling, Rouffignac cave, by chemical, stylistic and superimposition studies
}

Marine Gay, Frédéric Plassard, Katharina Müller, Ina Reiche

\section{- To cite this version:}

Marine Gay, Frédéric Plassard, Katharina Müller, Ina Reiche. Relative chronology of Palaeolithic drawings of the Great Ceiling, Rouffignac cave, by chemical, stylistic and superimposition studies. Journal of Archaeological Science: Reports, 2020, 29, pp.102006. 10.1016/j.jasrep.2019.102006 . hal02415053

\section{HAL Id: hal-02415053 \\ https://hal.science/hal-02415053}

Submitted on 17 Jul 2020

HAL is a multi-disciplinary open access archive for the deposit and dissemination of scientific research documents, whether they are published or not. The documents may come from teaching and research institutions in France or abroad, or from public or private research centers.
L'archive ouverte pluridisciplinaire HAL, est destinée au dépôt et à la diffusion de documents scientifiques de niveau recherche, publiés ou non, émanant des établissements d'enseignement et de recherche français ou étrangers, des laboratoires publics ou privés. 


\title{
Relative chronology of Palaeolithic drawings of the Great Ceiling, Rouffignac cave, by chemical, stylistic and superimposition studies
}

\author{
Marine Gay ${ }^{\mathrm{a}, \mathrm{b}}$, Frédéric Plassard ${ }^{\mathrm{c}}$, Katharina Müller ${ }^{\mathrm{a}, \mathrm{d}}$ and Ina Reiche $\mathrm{a}^{\mathrm{a}, \mathrm{d}, \mathrm{e} 1}$ \\ ${ }^{a}$ Sorbonne Universités, Université Paris 6, Laboratoire d'Archéologie Moléculaire et Structurale, UMR 8220 CNRS - Université Pierre et \\ Marie Curie, 4 place Jussieu, 75005 Paris, France \\ ${ }^{\mathrm{b}}$ Université de La Rochelle, Littoral Environnement et Sociétés, UMR 7266, 2 rue Olympe de Gouges, 17000 La Rochelle, France \\ ${ }^{\mathrm{c}}$ Université de Bordeaux, UMR 5199, PACEA, Allée Geoffroy Saint-Hilaire, CS 50023 - 33615 Pessac Cedex, France \\ ${ }^{\mathrm{d}}$ Rathgen-Forschungslabor, Staatliche Museen zu Berlin-Stiftung Preußischer Kulturbesitz, Schloßstraße 1a, 14059 Berlin, Germany \\ ${ }^{\mathrm{e}}$ PSL University, ENSCP, Institut de Recherche de Chimie Paris, UMR 8247 CNRS, PCMTH team, Centre de recherche et de restauration \\ des musées de France, 14 quai François Mitterrand, 75001 Paris \\ ${ }^{1}$ Corresponding author: ina.reiche@ chimieparistech.psl.eu
}

\section{Keywords}

Rouffignac cave, Great Ceiling, Palaeolithic black drawings, in situ non-invasive analysis, X-ray fluorescence, barium-containing manganese oxides, stylistic and superimposition study.

\begin{abstract}
This paper presents the first systematic chemical study of the black pigments used on the Great Ceiling panel at Rouffignac Cave in combination with stylistic and superimposition studies. A refined quantification strategy was designed to address the large number of drawings and the considerable amount of data required for the effective study of the specific black compositions on the Great Ceiling. We show that at least three different types of barium-bearing manganese oxides (that could be assimilated to different black raw coloring materials) were used. The new chemical data obtained are interpreted in light of stylistic and superimposition analyses of the figures. The grouping of the figures in small sub-sets according to chemical composition and consideration of superimpositions allowed for a complete re-reading of this complex panel and suggests that a small group of artists, each using different crayons, may have drawn the figures in a short period of time.
\end{abstract}

\section{Introduction}

Palaeolithic rock art is one of the oldest testimonies of representational artistic expression and of the beliefs and ritual practices of our ancestors. Renowned examples of decorated caves such as Altamira in Spain and Lascaux in France display an abundance of panels with overlapping images, painted in various colors, drawn, or engraved (Breuil, 1952; LeroiGourhan, 1965; Lorblanchet, 2010). Since their discovery and recognition as art, many studies have been conducted to reveal the meaning of their complex arrangements and to understand how, when and why they were created. Understanding the organization of the figures that compose the impressive panels of Palaeolithic cave art is a central archaeological and arthistorical issue. Detailed studies of rock art have sought to identify various distinct steps in the decoration of cave walls and ceilings in order to provide a relative chronology of the creation of the figures when direct dating of the prehistoric pigments is not possible. The combination of several analytical approaches (stylistic, physicochemical, and superimposition of the drawings) is essential to such studies. This is the basis of our present work. An in-depth, systematic study of a major panel of Rouffignac cave was performed to determine the use of different pigments in its creation as a promising line of research. Thus, a systematic chemical study of the Great Ceiling drawings complements stylistic and superimposition studies already carried out. It provides essential new insight into the creation and interpretation of the panel, structuring its organization in the absence of absolute dating possibilities.

Cave art can be directly dated using radiocarbon dating if carbon-based pigments were used in its creation (Lorblanchet, 1994; Quiles et al., 2016). However, preserved prehistoric pigments are most commonly minerals with no organic components that would allow for C-14 dating. The stylistic study of the technical and thematic evolution of rock art over time (Breuil, 1952) and the study of the superimposition of images (Aujoulat, 2004; Lorblanchet, 2010) have been used to clarify the chronology of images and distinguish between different phases of creation. For example, N. Aujoulat (2004) studied the famous "Salle des Taureaux" at Lascaux (Dordogne, France) and found that it was apparently created in three phases. During each phase, monothematic groups of animal representations were drawn (first the horses, then the aurochs and finally the deer) (Aujoulat, 2004). The study by M. Lorblanchet (2010) of the 25 overlapping black drawings (horse, bison, mammoth, and aurochs) of the "Frise noire" of Pech-Merle cave (Lot) revealed five distinct phases of creation. Others examples can be cited, coming from Australia (Chippindale and Taçon, 1998), where the relative chronology of the creation of complex decorative panels takes into account the figures style (nature of the figure, size and color used,) the creation technique of the figures, the superimposition of the representations and the conservation state both of the pictorial matter and of the bedrock, and is combined with absolute dating. Stylistic and superimposition studies, however, have certain limitations. More detailed studies, including physicochemical analyses, are required to further enrich our understanding of Palaeolithic cave art.

The first such physicochemical analyses, mostly focused on pigments, were carried out on samples from important prehistoric caves such as Altamira, Niaux, Lascaux and La Garma using electron microscopy (SEM, SEM-EDX and TEM) and X-ray absorption spectroscopy (XAFS) to access the artists' techniques and to understand the operational sequence of prehistoric painting activities (Cabrera-Garrido, 1978; Ballet, 1979; Vandiver, 1983; Clottes et al., 1990; Menu and Walter, 1992; Chalmin et al., 2003; Vignaud et al., 2006; Arias et al., 2011). During the last decade, important progress made in the 
development of portable systems for non-destructive analysis has facilitated greater access to valuable works of art like Palaeolithic rock art, and thus enabled an increasing number of studies to be conducted while preserving the integrity of the artwork (de Sanoit et al., 2005; Roldán et al., 2010; Lahlil et al., 2012; Nuevo et al., 2012; Beck et al., 2012 and 2014; Olivares et al., 2013; Gay et al., 2015 and 2016; Sepulveda et al., 2015; Wallis et al., 2016; Mauran et al., 2019).

Portable XRF spectrometry (pXRF) is a particularly suitable method for the in situ study of rock art, allowing for the quick and non-destructive identification of the elemental composition of pigments. Quantification is however challenging because of the heterogeneity of the analyzed material, in terms of the composition of the pigments and underlying rock surfaces, variable thickness of pigments applied. The karst environment also contributes to the complexity that can be encountered when applying pXRF to rock art: accessibility of art deposited on walls and ceiling, and uneven surfaces (geometric constraints) will depend directly on it, and with it, the use of a spectrometer device the handler (Huntley 2012). All of these difficulties, as well as the scope of work and time required (for work in the field and the evaluation of the data), have to be taken considered in the development of quantitative procedures specific to each individual cave (Gay et al., 2016).

\section{The Rouffignac cave}

The cave of Rouffignac, also referred to as "the cave of a hundred mammoths" is famous for the striking number of mammoth representations (160), which account for about 30\% of all mammoth representations inventoried in prehistoric rock art to date (Barrière, 1982; Plassard, 2005). Rouffignac Cave is one of the most prominent caves of the Vézère Valley, a major locus of Palaeolithic rock art classified as a UNESCO World Heritage Site in 1979. Its entrance has remained open since the Pleistocene and the cave has long been visited in more recent centuries, as indicated by many graffiti. However, the Palaeolithic rock art was only discovered in 1956 by Louis-René Nougier and Romain Robert (Nougier and Robert, 1957). The vast cave network comprised of nearly ten kilometers of galleries houses 250 engravings and black drawings, sometimes arranged in impressive compositions as in the example of the Great Ceiling panel. The art has been stylistically assigned to Leroi Gourhan style IV (Leroi Gourhan, 1965). However, new discoveries at the end of the twentieth century, in particular the discovery of the Chauvet Cave, overturned the current system based on a linear stylistic evolution of the Palaeolithic rock art (Valladas and Clottes, 2003; Fritz, 2017). Yet, it is still possible to accept the Rouffignac art attribution to the recent phase of the emblematic Middle Magdalenian period, whose is well-documented in other caves and rock-shelters in the region, such as Font-de-Gaume, Les Combarelles, Bernifal or Cap-Blanc, or in other occupied shelters, such as Laugeriebasse or la Madeleine (Tosello, 2003; Plassard, 2005; Bourdier, 2010).

The Great Ceiling is a major and singular ornamented panel in Rouffignac, on which a fourth of the total number of compositions are concentrated on a surface of less than $40 \mathrm{~m}^{2}$ (Fig. 1).

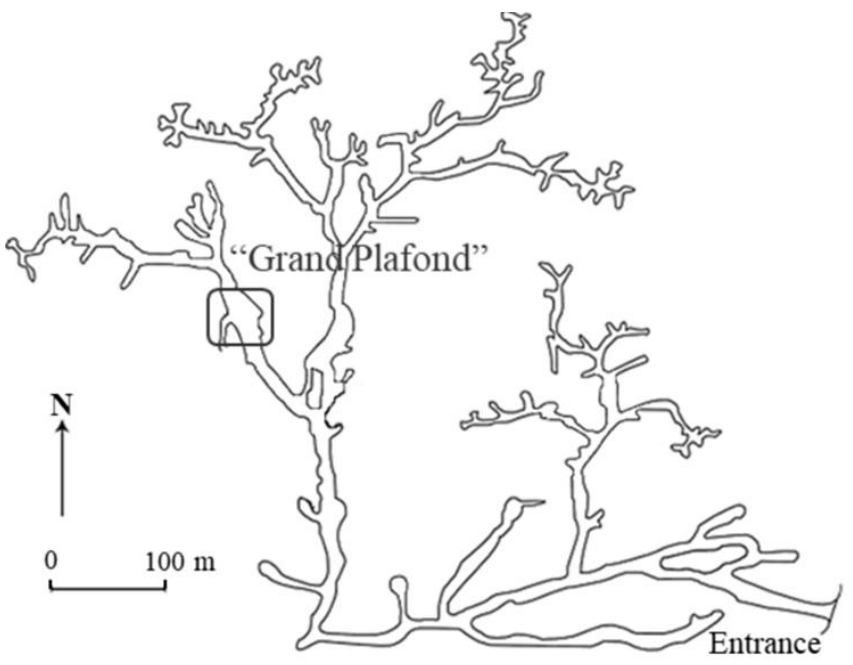

(single column fitting image)

Fig. 1: Map of Rouffignac Cave (according to Plassard, 2005) with the Great Ceiling ("Grand Plafond") indicated.

The five principal animal species in the cave (mammoth, bison, ibex, horse, and wooly rhinoceros) are represented on it in the form of black figures that overlap each other and vary in size and orientation (Barrière, 1982). Even the largest animal on the Great Ceiling, a horse $2.70 \mathrm{~m}$ long was executed without distortion even though the floor of the cave was less than one meter below the ceiling in the Palaeolithic era. This evidences the remarkable artistic performance of its creators.

The creation technique of all the figures is the same and consists in drawing with dry matter. Indeed, the black matter from the strokes is agglomerated or adhered on one side of contact surfaces, but not on the other side (Fig. 2). These contact surfaces can be asperities of the substrate or relief. If it was moist painting matter, it would have covered entirely these irregularities. Moreover, these observations allow attesting the direction of the linear stroke. 


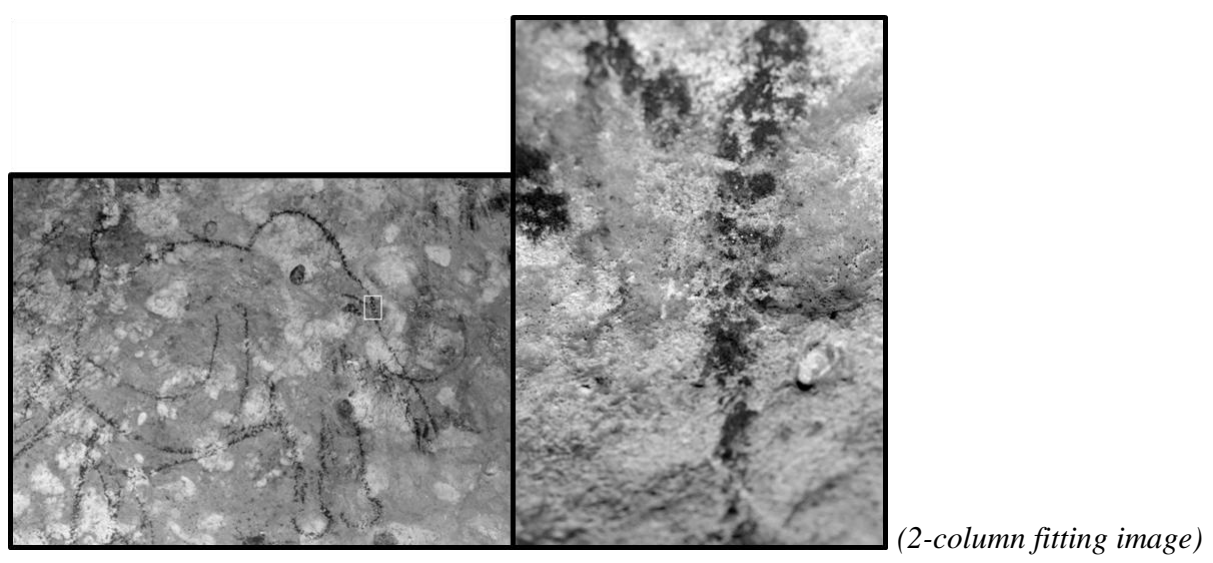

Fig. 2: Left: Macrophotography of the mammoth 121. Right: The side of the agglomerated matter on the wall substrate indicates the direction of the stroke.

No testimony of the use of crayons, commonly defined as faceted blocks showing signs of wear (Salomon, 2009; Dayet 2013, Chalmin and Huntley, 2017) has been found at Rouffignac Cave. Thus, the notion of dry raw coloring material seems more suitable in this studied case. The term of moist painting matter appears incorrect, given the macroscopic observation of the deposit of the black matter on the bedrock.

In the midst of this turmoil of images, with homogeneous style and application technique, no master plan of its realization brings out, become unreadable as a result of an accumulation of too many images. Despite a lack of coherence, the desire to comprehend the organization of these drawings and the will to identify various distinct steps in the decoration in order to access to a relative chronology of the creation of the figures lead to different detailed studies including stylistic and superimposition observations as well as physico-chemical analyses.

\section{Previous studies and new issues}

The stylistic study of art at Rouffignac Cave has been conducted since the earliest research in the cave in 1959 (Nougier and Robert, 1959). The authors of these studies (Leroi-Gourhan, 1965; Barrière, 1982; Plassard, 1999 and 2005) are in agreement that all of the figures share stylistic similarities with each other and with the rock art from other caves such as Font-deGaume and Combarelles.

The organization of the drawings on the Great Ceiling was first interpreted as animal groups distributed in a semi-circle around the entryway to the gallery, entering or leaving it (Barrière, 1980). More recently, F. and J. Plassard (2016) reinterpreted the composition based on superimposition studies and concluded that the Great Ceiling is a juxtaposition of monothematic or more complex ensembles, associated with single representations. However, the understanding of the overall organization of the Great Ceiling panel is still incomplete.

Preliminary chemical studies on samples from Rouffignac as well as isolated in situ analyses of a few drawings not only confirm the exclusive use of manganese (Mn) oxide-based pigments in the Palaeolithic figures in the cave, but additionally demonstrate that it is possible to distinguish between different kinds of Mn oxide (Grazioso, 1956; de Sanoit et al., 2005; Lahlil et al., 2012; Beck et al., 2012 and 2014). Anyhow, any relationship could not be established between the use of one kind of Mn oxide and the species, the size or orientation of the animals represented yet.

Based on these early results and the lack of chemical information for most of the drawings, a systematic chemical study of the Great Ceiling drawings is engaged to provide essential new insight into the creation and interpretation of the panel.

Specific research questions addressed in this study include:

1. Is it possible to define characteristic chemical fingerprints for the specific pigments used in the creation of each prehistoric figure based on in situ chemical analyses by pXRF?

2. Can groups of figures be defined according to the chemical signatures of specific pigments?

3. Is there a relationship between specific chemical signatures and the types of animals depicted?

4. Do chemical data support stylistic classifications of the figures or do they suggest a new interpretation of the drawings (or panel composition)?

5. Do the chemical data support the chronological order of the execution of the figures proposed by the superimposition study?

Furthermore, does the combination of chemical, stylistic and superimposition data provide new insights into the process of creation of the panel? Can conclusions be drawn regarding: 
6. The identification of different hands (individual artists or groups of artists) and their assignment to distinct figures or figure groups?

7. The relative chronological sequence of the figures?

8. The identification of distinct phases of creation in different time periods (intervals of one generation to several or even many generations) or, in contrast, the quasi contemporaneity of the figures?

Interpretation of the data is based on several assumptions. One, that the chemical composition of a pigment is homogeneous within the strokes that form an individual figure and could imply that one figure was made in one session with one type of particular raw coloring material. Second, the applied analytical method is sensitive enough to distinguish between different raw coloring materials used by means of the analysis of the strokes on the wall. Thirdly, a specific chemical signature could be then attributed to a particular dry fragment of homogeneous raw material supposed homogeneous, with a common geological origin, assuming that the geological source of the raw material is also homogenous. Though various scenarios can be hypothesized for the creation process of the panel, we consider it most likely that one artist or a small group of artists used a specific type of raw coloring material at any given time. Furthermore, if two figures created with pigments of different chemical compositions overlap, the figures must necessarily have been created in succession, one before the other. However, the time interval between the creations of these figures could vary widely and will be discussed on the basis of our new results. Therefore, combining chemical data with the other forms of information available is crucial to the development of new interpretations.

\section{Materials and Methods}

\subsection{Challenges of in situ chemical analysis in karst contexts}

A total of 44 drawings from the Great Ceiling with three to five measurements per figure was analyzed at representative locations depending on accessibility (Fig. 3b). Several measurements had to be performed on the lines of the figures and on the bedrock next to them so that statistically relevant data could be obtained for each figure or parts of a figure. In all, 212 analyzed points on the pigment and 82 analyzed points on the bedrock have been performed (Appendix Table A and Table B). The Great Ceiling as a whole presents a remarkable state of conservation. Any taphonomic phenomenon, as coating, crust or other mineral accretion, doesn't affects both the pigment layer and the substrate, which simplifies the choice of the location of the analyzed point. The applied pXRF spectrometer was well adapted to the particular working conditions of a cave environment, given its high flexibility, minimal weight, and ease of handling. This was even more important as the animal drawings are not easily accessible at the cave's ceiling, currently 2.40 meters above the cave floor (Fig. 3a). The primary spectrometer is a non-commercial device composed of a $40 \mathrm{kV}$ MOXTEK X-ray tube with a palladium anode and a beam-spot size of approximately $1 \mathrm{~mm}^{2}$ on the sample achieved with a collimator. A $7 \mathrm{~mm}^{2}$ Silicon Drift Detector with an energy resolution of $140 \mathrm{eV}$ (FWHM at $5.9 \mathrm{keV}$ ) was used to collect the XRF signal. The X-ray tube and detector are fixed in $45^{\circ} / 90^{\circ}$ geometry on a positioning system that allows micrometric movements. The head of the detector is at a distance of $5 \mathrm{~mm}$ of the analyzed surface. The spectrometer is mounted on a stable tripod. The measurement conditions were $30 \mathrm{kV}$, $300 \mu \mathrm{A}$, and $300 \mathrm{~s} /$ measurement.

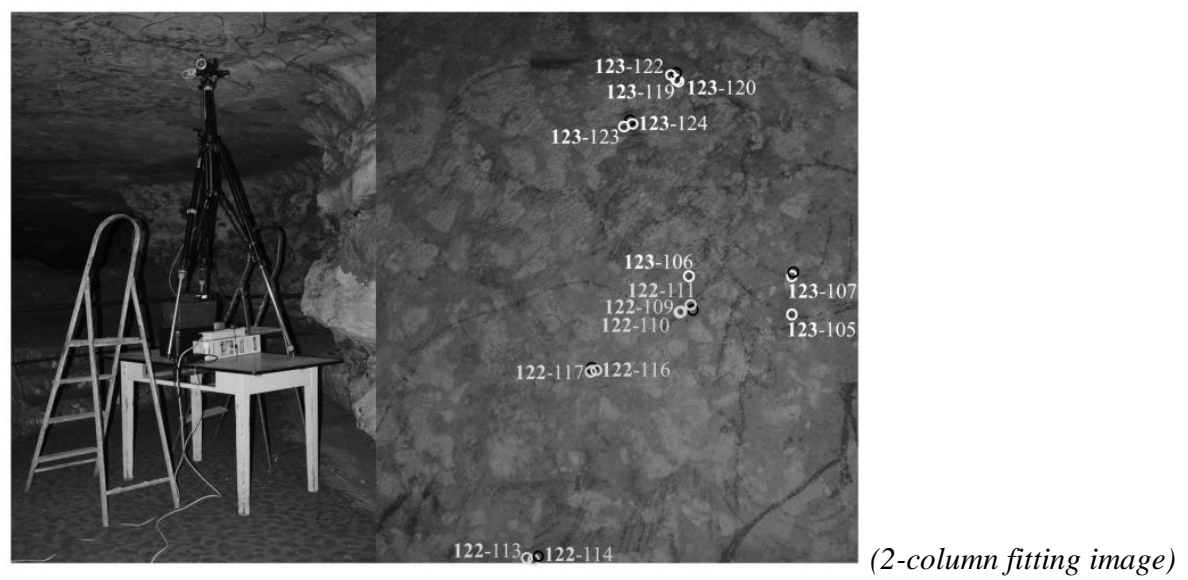

Fig. 3: a) Portable XRF spectrometer used in the analysis of the black drawings on the Great Ceiling. b) Multiple measurements at different locations on a single figure (bright points) and on the wall substrate (black points) were performed to acquire statistically relevant XRF data and to evaluate the heterogeneity of the cave wall: the example of Mammoths 122 and 123.

Additionally, two slightly different spectrometer set-ups were used in the analysis of Rouffignac's rock art during a total of seven three-day measurement campaigns between 2009 and 2016 (de Sanoit et al., 2005; Beck et al., 2012 and 2014; Gay et al., 2016). They differ in terms of the type of components (X-ray tube and/or detector) and in the geometry of the device (position of the X-ray tube and the detector with regard to each other and to the analyzed surface). The performance of the 
three set-ups can be considered equal (see de Sanoit et al., 2005 and Beck et al., 2012 and 2014 to a detailed description of the two devices) and the results obtained were tested as equivalent (Appendix Table C).

\subsection{Quantification of analytical data}

Quantification of the results poses an analytical challenge due to a suite of complicated conditions:

- $\quad$ the small quantity of pigment

- the heterogeneity of both the thickness of the pigment layers and the composition of the underlying cave wall. It must be taken into consideration that the signals captured from the pigments and the cave wall cannot be easily separated. The influence of the composition of the wall on the spectra obtained from the pigments varies as a function of the thickness and density of the applied pigment (Gay et al., 2016).

- the X-ray incidence and detection angles are difficult to control due to the uneven surface of the cave wall at macroand micro-scales, which may introduce some inter-measurement variations that are difficult to control for.

Nevertheless, the composition of the black pigments can be (semi)-quantified in terms of the three main constituents of the pigments: manganese oxide $\left(\mathrm{MnO}_{2}\right)$, barium oxide $(\mathrm{BaO})$ and iron oxide $\left(\mathrm{Fe}_{2} \mathrm{O}_{3}\right)$ (for the complete data set see Appendix Table A). The $\mathrm{MnO}_{2}$ and $\mathrm{BaO}$ contents of the cave wall are negligible and $\mathrm{Fe}_{2} \mathrm{O}_{3}$ is found in the cave wall to a much lesser extent than in the pigment. Therefore, these oxides can be considered chemical markers for the pigment (Fig. 4).

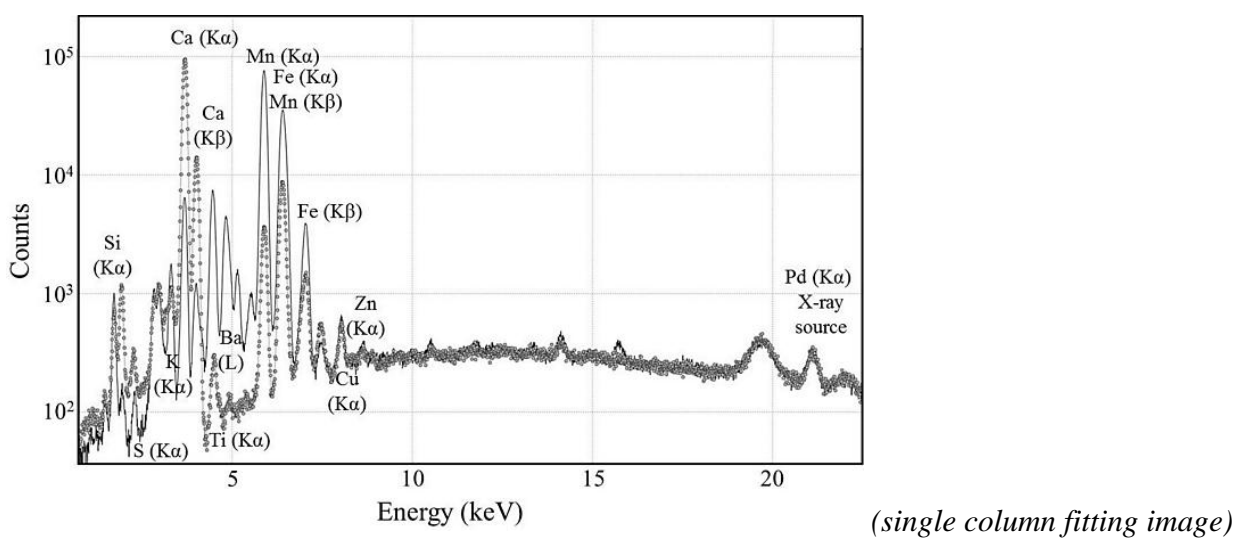

Fig. 4: XRF spectra obtained for the black pigment of the horse 84 measurement point 201 referenced 84-201 (continuous line) and the wall substrate right next referenced 84-203 (dotted line). These two XRF spectra are representative of the whole spectra of this study.

Two different procedures to semi-quantify the three oxide concentrations have been implemented through the previous studies, the fundamental parameter method (Beck et al., 2012 and 2014; Gay et al., 2016) and Monte Carlo simulations (de Sanoit et al., 2005). Monte Carlo simulations are very time-consuming, and the fundamental parameter method turned out to be more efficient and better suited to our large XRF datasets and was therefore used exclusively in this analysis. The XRF spectra were fitted using PyMca software (Solé et al., 2007). The sum of the three main constituents $\left(\mathrm{MnO}_{2}, \mathrm{BaO}\right.$ and $\left.\mathrm{Fe} \mathrm{O}_{3}\right)$ was normalized to $100 \%$, rendering measurement data comparable and independent from flux variations between different analyses. Although the wall contains a trace amount of $\mathrm{Fe}_{2} \mathrm{O}_{3}$ it is considered negligible with respect to its content in the pigment. Therefore, the subtraction of the substrate signal from that of the pigment layer was not necessary (Gay et al., 2016).

\subsection{Stylistic study}

The stylistic study of the Great Ceiling is based upon observations of the contexts and graphic conventions of the figures: the determination of the number of animals belonging to a species, and location of these animals in relation to others and the identification of associated themes, the description of the technique(s) used for drawing, the description of the animal profile and its degree of completion, the indication of anatomical elements related to a pictorial theme (sexes, legs, bellies, tails, eyes, tusks, horns, humps, etc.). Some of these details are highly relevant to the chronological attribution of the style. Thus, the presence of tectiforms and the anatomical precision of some of the figurative details such as the horses' heads and hooves, or the mammoths' bilobed trunks and anal flaps are considered typical of Leroi-Gourhan's Style IV.

\subsection{Superimposition study derived from F. and J. Plassard (2016)}

The superimposition study was based on the compared observations of four different observers, made with the naked eye or with the help of a magnifying glass, of all overlapping or intersecting figures. In addition, the graphic elements and stylistic conventions chosen by the Palaeolithic artists have been considered in this study. These stylistic conventions included, for example, the orientation of the animals relative to one another (facing each other or not) and the fact that in some cases the artist obviously avoided drawing over an already existing figure when creating a new one. Each series of superimposed 
motifs, when they are observable, can be assimilated to an archaeological stratigraphy and can therefore be presented in a form of a Harris matrix (Harris and Gunn, 2017). A Harris matrix was thus constructed to evidence the superimposition relationships between figures. The construction of the matrix is based on the relations that the stratigraphic units maintain between themselves represented with lines and boxes: the figure of one ensemble is indicated in a box and connected by a line to another figure. A vertical line represents the chronological relationship of one unit being later than another (the younger event on the top) and a double horizontal line the relationship of equivalence or contemporaneity. Therefore, each Harris matrix should be read from the base to the top.

\section{Results}

\subsection{Summary of the stylistic study}

At the scale of the Great Ceiling, the stylistic similarity of the figures is underlined by their technical homogeneity, even in the absence of a structured organizational layout. The small stylistic differences between pictures are not correlated with the compositional groups, such as groups of facing animals. Therefore, these small differences are not enough to define distinct stylistic groups. Nevertheless, some anatomical details depicted on the animals, such as the fat hump on bison or the horns of ibex, allow us to identify groups of pictures with stylistic similarities even if it is not possible to decide if these reflect stylistic choices or natural anatomical diversity.

\subsection{Summary of the superimposition study derived from F. and J. Plassard (2016)}

Approximately half of the 65 drawings showed intersections between the drawings of distinct figures in the superimposition study. Only 27 superimpositions of strokes were observed in a total of 33 drawings (Appendix Table B). The compilation of superimposition data, combined with graphical and stylistic elements of the figures that were deemed significant, allowed the images to be classified into several subgroups. The construction of a Harris Matrix enables to highlight these subgroups (Fig. 5). This approach has already proved its efficiency to precise the stratigraphic sequence of an art panel in different contexts (Harris and Gunn, 2017).
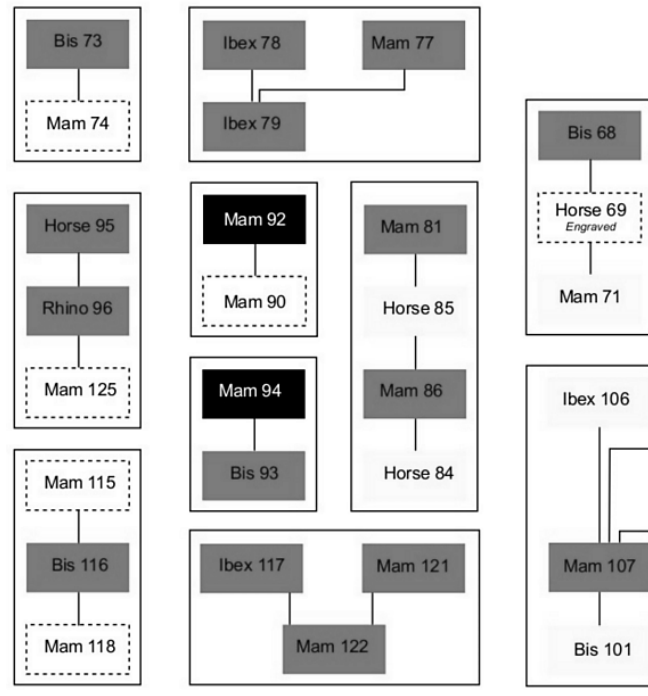

Fig. 5: Harris Matrix of the Great Ceiling, Rouffignac cave, Dordogne. Each series of superimposed motifs, when they are observable, can be assimilated to an archaeological stratigraphy and can therefore be presented in the form of a Harris matrix (Harris and Gunn, 2017). Each Harris matrix must be read from the base to the top ; the vertical line indicate the stratigraphic relationship (the younger event on the top) and the double horizontal lines indicate a chronological equivalence.

As illustrated by the Harris matrix depicted in Fig. 5, the subgroup with Mammoths 120 to 123 creates a small frieze with superimpositions and reserve between the pictures.

Mammoth 125, Rhinoceros 96 and Horse 95 can be considered as a second subgroup. The horse was drawn after the mammoth and the rhinoceros, although it is the largest picture on the ceiling. This observation contradicts the classical hypothesis that the biggest drawings are central to the organization of the panel and were drawn first (Barrière, 1980).

A last example of a subgroup is a complex set of drawings located around Mammoth 107. The sequence of execution established by the patterns of superimpositions and several graphic elements, such as certain lines that deviate to respect lines already present, is as follows: first the forehead of Bison 126, followed by Bison 101, whose backline respects the outline of the forehead of Bison 126; Mammoths 107 and 111 came after and, finally, Ibexes 106, 109 and 110.

5.3. Chemical study. The composition of the strokes on the ceiling as chemical signature of specific raw coloring material 
As no crayons have been found at Rouffignac Cave, the chemical compositions of the pigments on the wall are the only sources of data on the coloring material used. The composition of pigments obtained from several pXRF measurements on a given drawing has proven to be generally homogeneous, and average values are used as representative compositional values of the figures (Appendix Table A). This supports our hypothesis that a characteristic chemical composition would be indicative of a specific coloring material; be it in the form of a raw material fragment or as transformed matter. Thus, chemical fingerprints were defined for various pigments used in the creation of individual figures. These chemical characteristics can be correlated to the use of raw material of a specific origin. In a first approximation, we will suppose that material from the same geological source might have similar compositions. In this case, though, it could still indicate (especially with the combined superimposition data) the same supply of raw material, e.g. a group arrives together having collected their raw coloring material at the same location on the way to the cave. At the same time, if different artists from different places met in the cave to create the drawings, each artist might have raw material from a different source.

\subsection{Distinguishing different groups of figures according to the chemical composition of the pigment strokes}

Our comprehensive dataset suggests the existence of three chemical groups of figures predominantly based on differences in the $\mathrm{BaO}$ contents contained in their outlines (Fig. 6). The first group is characterized by very low $\mathrm{BaO}$ concentrations, ranging from $2 \%$ and $3 \%$ (very-low $\mathrm{BaO}$-group). A second group with low to intermediate $\mathrm{BaO}$ contents of up to $10 \%$ has been defined (intermediate $\mathrm{BaO}$-group). The pigments belonging to the third group (high $\mathrm{BaO}$-group) contain significantly higher $\mathrm{BaO}$ concentrations ranging from $16 \%$ to $27 \%$. The ternary diagram also shows great dispersion of $\mathrm{Fe}_{2} \mathrm{O}_{3}$ values. 


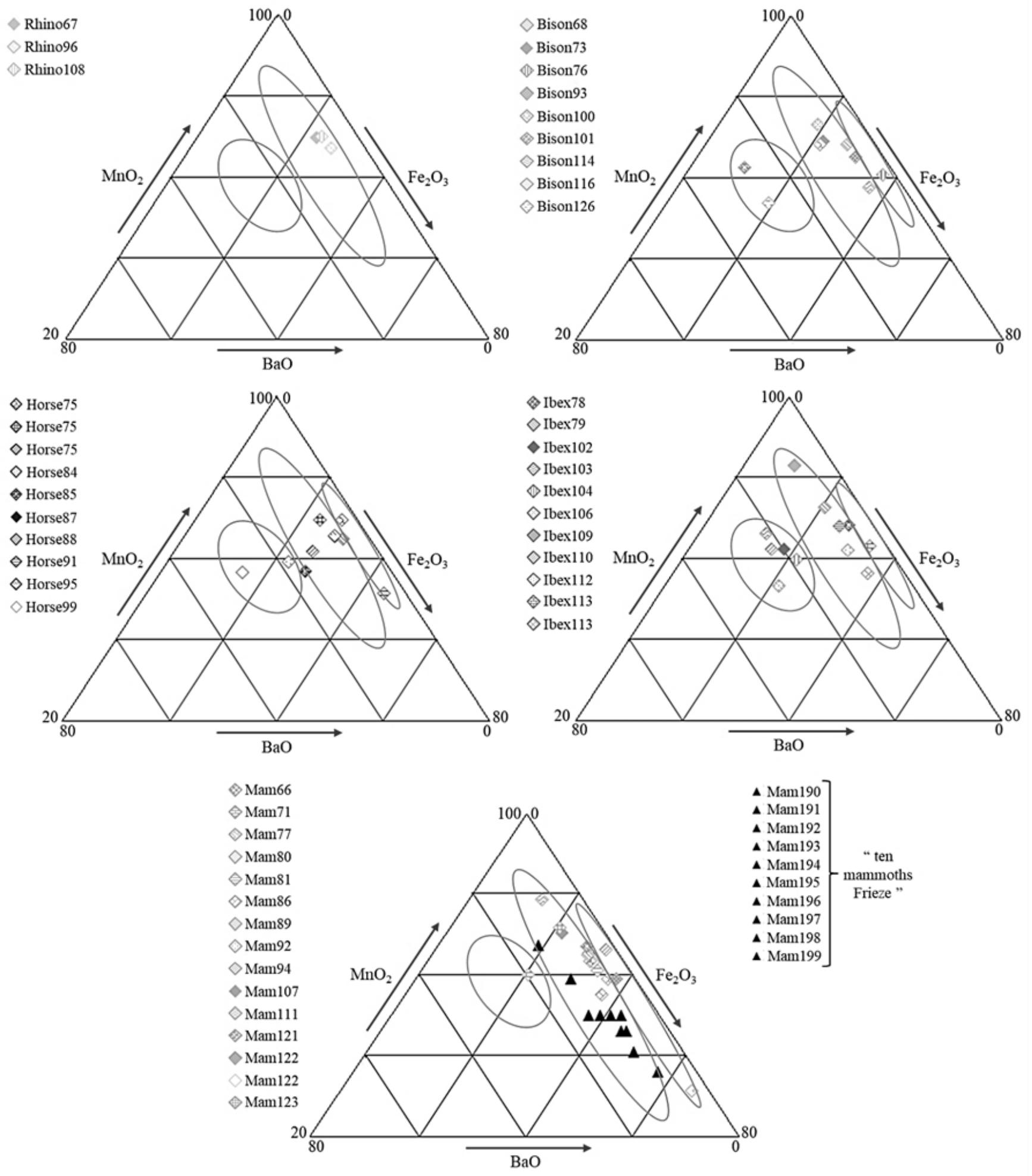

(2-column fitting image)

310 Fig. 6: Ternary diagrams of the three main oxide concentrations $\left(\mathrm{MnO}_{2}, \mathrm{Fe}_{2} \mathrm{O}_{3}\right.$ and $\left.\mathrm{BaO}\right)$ characterizing the black pigments of the Great 311 Ceiling and of the "Ten Mammoths Frieze" at Rouffignac Cave, including data from this study and the available literature (de Sanoit et al., 312 2005; Beck et al., 2012 and 2014; Gay et al., 2016). The data are grouped according to the animal species represented to enhance clarity of 313 the plots. The three groups are indicated by ellipses.

A clear interpretation of the $\mathrm{Fe}_{2} \mathrm{O}_{3}$ concentration values is not possible due to a small and varying Fe content in the cave wall substrate, which affects the pigment signal more or less as a function of the thickness of the pigment layer.

Figure 7 provides an overview of the analytical data obtained from the Great Ceiling and illustrates the chemical classification of the drawings in three different groups, indicating the use of a minimum of three different crayons. 


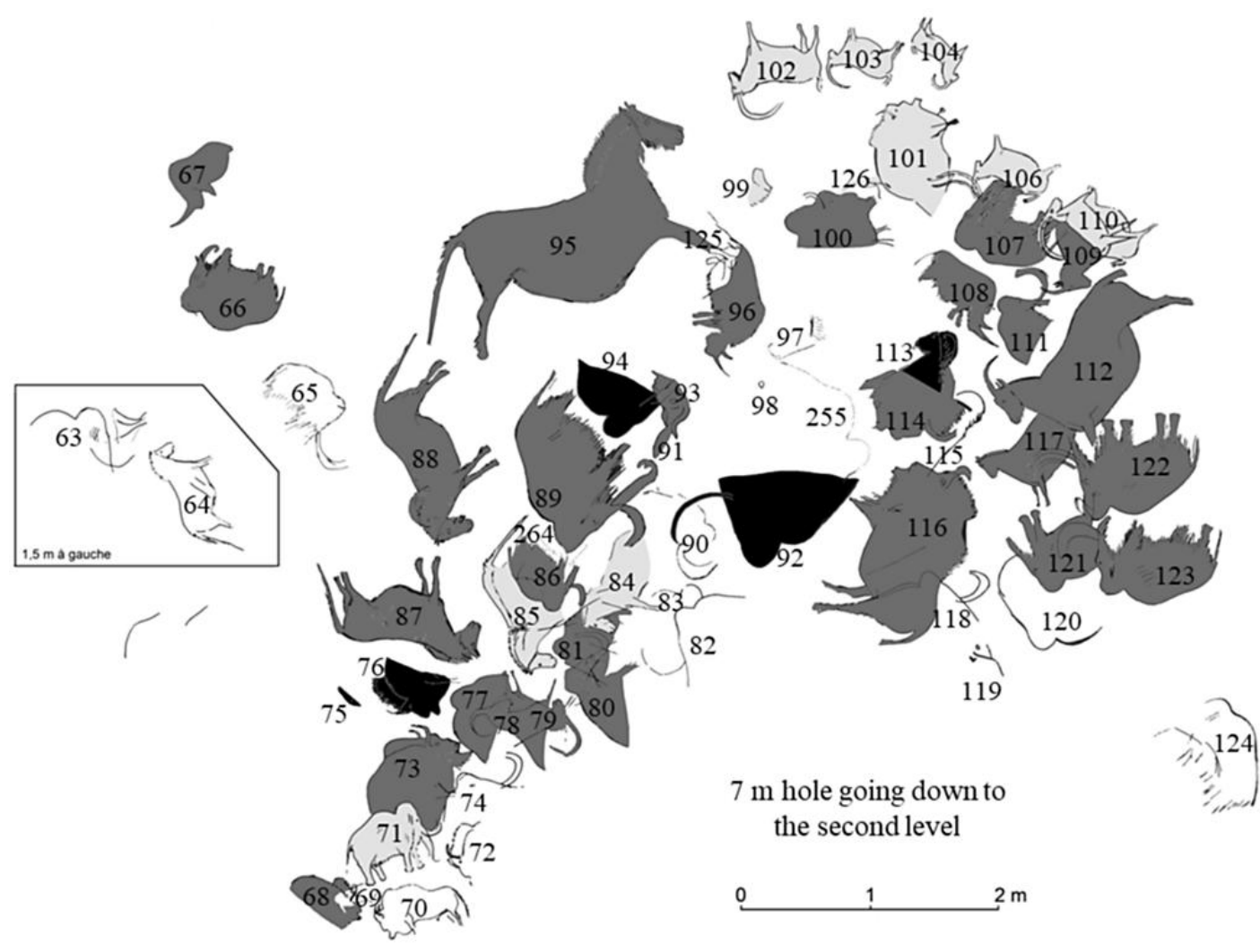

320

321

322

323

324

325

326

327

328

329

330

331

332

333

334

335

336

Fig. 7: Visualization of all analytical data in the general survey of drawings on the Great Ceiling. The different chemical groups are indicated: very-low $\mathrm{BaO}$ group (black), intermediate $\mathrm{BaO}$ group (dark-gray), high $\mathrm{BaO}$ group (light-gray) and inaccessible figures, not studied (not colored).

The three chemical groups identified in this study are consistent with the use of at least three different variants of black pigment (or mixtures of pigment) consisting of different amounts of the minerals pyrolusite $\left(\mathrm{MnO}_{2}\right)$, corresponding at the low end of the range to the very-low $\mathrm{BaO}$ group, and of romanechite $\left(\mathrm{Ba}_{2} \mathrm{Mn}_{5} \mathrm{O}_{10}\right)$, corresponding to the high end of the range to the high $\mathrm{BaO}$-group. These $\mathrm{Mn}$ oxides have been identified in a preliminary study using portable X-ray diffraction (Lahlil et al., 2012; Beck et al., 2012 and 2014). The majority of the studied animal representations belongs to the very-low and intermediate $\mathrm{BaO}$-groups, thus to pyrolusite and pyrolysite mixed with another Ba-containing Mn oxide like romanechite. No relationship was observed between the chemical groups and the animal species represented (Table 1). The chemical groups are apparently partly contradictory to those defined by stylistic/superimposition studies.

Table 1: The classification of the black animal drawings of the Great Ceiling in three chemical groups according to concentrations of the main constituents of the pigments.

\begin{tabular}{|c|c|c|c|}
\hline Drawing & Very-low BaO-group (2-3 \% BaO) & 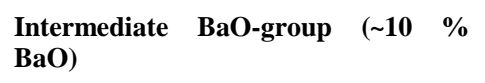 & High BaO-group (16-27 \% BaO) \\
\hline $\begin{array}{l}\text { Woolly } \\
\text { rhinoceros }\end{array}$ & & $67,96,108$ & \\
\hline Bison & 76 & $68,73,93,100,114,116$ & 101,126 \\
\hline Mammoth & 92,94 & $\begin{array}{l}66,77,80,81,86,89,107,111,121 \\
122,123\end{array}$ & 71 \\
\hline Horse & 75 & $87,88,91,95$ & $84,85,99$ \\
\hline Ibex & 113 & $78,79,109,112,117$ & $102,103,104,106,110$ \\
\hline
\end{tabular}




\section{Discussion}

\subsection{Re-reading of the Great Ceiling crossing different studies}

The overall comparison of the data from superimposition, stylistic, and chemical studies does support a hypothesis of thematic structuring with one species drawn before another, as observed in other cases of prehistoric rock art, such as the "Frise noire" at Pech-Merle, the "Salle des taureaux" at Lascaux (Aujoulat, 2004; Lorblanchet, 2010).

As discussed in F. and J. Plassard (2016), the Great Ceiling cannot be interpreted as a unified composition. It is more appropriate to interpret the panel as an arrangement of several subgroups of images highlighted first by the stylistic and the superimposition studies, on which we have chosen to focus our discussion given the new chemical results.

\subsection{Insights on selected subgroups from the Great Ceiling}

\subsubsection{Re-reading of single-panel figures and evidence of a third chemical group}

The two cases discussed below illustrate particularly how chemical analyses can contribute to a new reading of the figures. The comprehensive chemical data obtained from the figures on the Great Ceiling allowed the definition of a third chemical group corresponding to the very-low $\mathrm{BaO}$-group $(\sim 3 \mathrm{wt} . \% \mathrm{BaO})$, which has not been identified before in the preliminary studies (Beck et al., 2012 and 2014). The identification of this new chemical group allows additional insights into the unity of specific figures.

First, the neighboring drawings of Ibex 113 and Bison 114 are considered (Fig. 8). The pigment compositions found for the front legs of Ibex $113(\sim 7 \mathrm{wt} . \% \mathrm{BaO}$, intermediate $\mathrm{BaO}$-group) are not in agreement with the ones obtained for the ibex muzzle, the back of its head and its horn $(\sim 3 \mathrm{wt} . \% \mathrm{BaO}$ respectively, very-low $\mathrm{BaO}$-group). Surprisingly, the chemical signature of the ibex legs corresponds perfectly to the one of the head of neighboring Bison 114. The chemical characteristics observed for these two figures may indicate that the lines initially interpreted as front legs of the Ibex 113 actually represent the front leg of Bison 114.

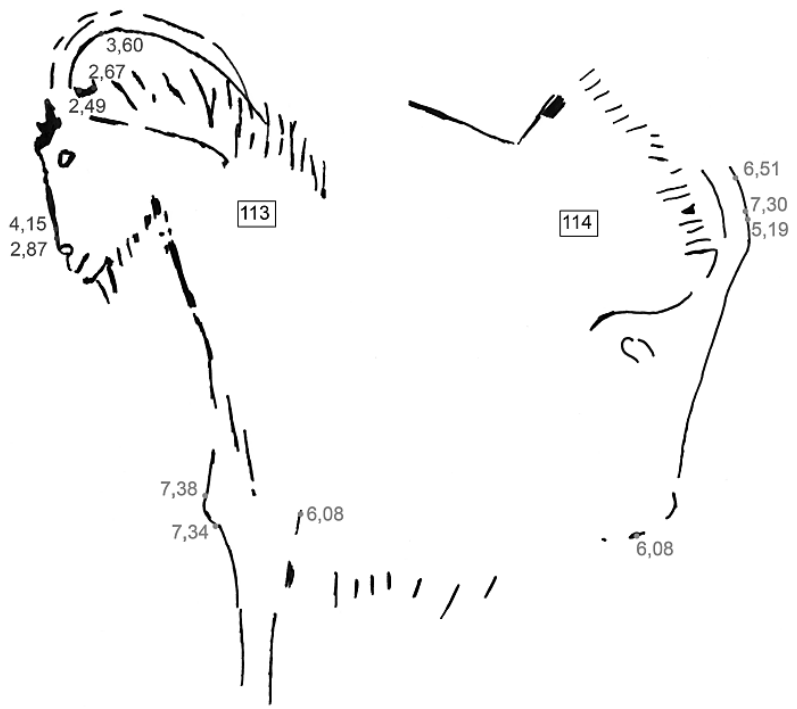

Fig. 8: Chemical analysis of two neighboring drawings, Ibex 113 and Bison 114, calling into question the attribution of the front legs of Ibex 113. The $\mathrm{BaO}$ concentrations (wt.\%) obtained are indicated for all XRF analysis locations.

Second, different chemical signatures were found for several drawing strokes attributes to Mammoth 122 . The $\mathrm{BaO}$ concentrations obtained for the lines inside the outline of this mammoth and the lines illustrating the fur on its legs differ from those of the line that forms the outline (6 and $3 \mathrm{wt} . \%$, respectively). This difference can be explained by a stylistic addition from the original artist itself or by another hand possibly at a later date, which we consider the more likely scenario.

\subsubsection{Evidence of the creation of sub-ensembles of the Great Ceiling}

The following example illustrates how combining the results stylistic, superimposition, and chemical studies provides new information on the sequence of actions that created the panel. The example is a complex ensemble of four distinct but 
overlapping stylistic subgroups (Fig. 9). Group 1 is a homogeneous set of mammoths (Mammoths 120-123), group 2 is a coherent structure of mammoths and ibexes (Mammoths 107 and 111, Ibexes 106, 109, 110, 112 and 117), group 3 is a monothematic set of ibexes (Ibexes 102-104) and group 4 is a triptych of bison (Bison 100, 101 and 126) (Fig. 9a).

The chemical analyses reveal the same chemical fingerprint for all of the mammoths in the homogenous group 1 . The results fall into the intermediate $\mathrm{BaO}$ group (Fig. 9b) and corroborate the conclusions of the stylistic and superimposition studies.
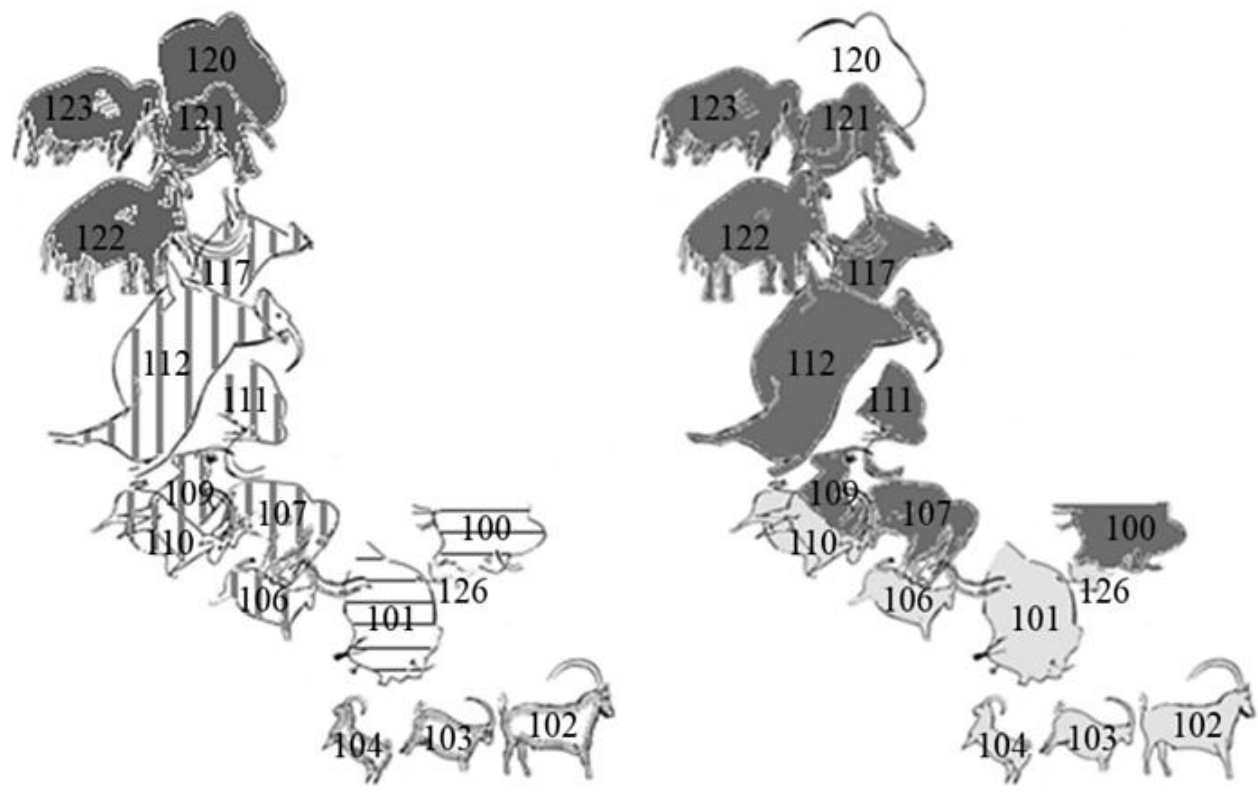

(single column fitting image)

Fig. 9: a) Superimposition interpretation: four distinct units consisting of a homogeneous set of mammoths (gray fill), a coherent layered group of mammoth and ibex (vertical stripes), a triptych of bison (horizontal stripes) and a set of ibexes (gray outline). b) The different chemical groups are indicated: intermediate $\mathrm{BaO}$ group (dark-gray), high $\mathrm{BaO}$ group (light-gray) and inaccessible figures, not studied (not colored).

An identical chemical fingerprint (intermediate $\mathrm{BaO}$-group) was found for all figures of the complex composition of mammoths and ibexes (group 2), except two of the ibexes (Ibexes 110 and 106) that show high BaO concentrations, placing them into the high $\mathrm{BaO}$ group. This suggests that these two ibexes could belong to the neighboring monothematic set of ibexes (group 3), which all belong to the high $\mathrm{BaO}$ group. In this case, the chemical data partly confirm the stylistic and superimposition studies and, moreover, provide evidence for the re-assignment of certain figures and thus a more accurate reading of the sub-panel composition.

Further, the chemical grouping determined for the triptych of bison (group 4) apparently contradicts the grouping of the three bison into a single unit, because Bison 100 belongs to the intermediate $\mathrm{BaO}$ group whereas the other two fall into the high $\mathrm{BaO}$ group. The superimposition of Bison 101 and 126 reveals that the backline of Bison 101 was broken to respect the forehead of Bison 126. These observations coincide with the chemical information and support the separation of the set of bison into two groups, with Bison 100 on one side and Bison 101 and 126 on the other side.

\subsubsection{Evidence for the sequential creation of subgroups on the Great Ceiling}

Considering the overlap patterns of these four groups, a new reading of the organization of this complex ensemble can be provided, even if the chronology of creation appears to be very complex. There are two groups of figures with superimpositions within them, and no superimpositions between the groups.

Table 2 summarizes the sequential information that can be deduced from the new observations and analyses. A part of this ensemble (group 1 and part of group 2) was started with Mammoths 120 to 122 then Ibexes 112 and 117. The other part (part of groups 2 and 4, and group 3), with no superimposition with the previous, was started with Bison 126 then Bison 101 . It was continued with Mammoths 107 and 111 and Ibex 109, looking to the left side, and then finished with Ibexes 110 and 106, looking to the right side and associated with Ibexes 102 and 103. Ibex 104 chemically belongs to the set of ibexes looking to the right side and was apparently drawn at last. Consequently, it seems that the two different black pigments were used in alternation: high $\mathrm{BaO}$ group for Bison 101, then intermediate $\mathrm{BaO}$ group for Mammoth 107 and 111 as well as for Ibex 109 and once again high $\mathrm{BaO}$ group for Ibexes 110, 106 and 102 to 104 . 
433

434

435

436

437

438

439

440

441

442

443

444

445

446

447

Table 2. The interpreted relative chronological sequence of the panel of four superimposed groups.

\begin{tabular}{l|l|l|l}
\hline Creation phase & \multicolumn{1}{|c|}{$\mathbf{1}$} & \multicolumn{1}{c}{$\mathbf{2}$} & \multicolumn{1}{c}{$\mathbf{3}$} \\
\hline Group 1 and part of group 2 & $\begin{array}{l}\text { Mammoths 120, 121, } \\
122\end{array}$ & Ibexes 112, 117 & \\
\hline Chemical results & $\begin{array}{l}\text { Intermediate BaO- } \\
\text { group }\end{array}$ & Intermediate BaO-group & \\
\hline Group 3 and part of groups 2 and 4 & $\begin{array}{l}\text { Bison 126 then Bison } \\
101\end{array}$ & $\begin{array}{l}\text { Mammoths 107, 111, } \\
\text { Ibex 109 }\end{array}$ & $\begin{array}{l}\text { Ibexes 110, 106 } \\
\text { Ibexes 102, 103, 104 }\end{array}$ \\
\hline Chemical results & High BaO-group & Intermediate BaO-group & High BaO-group \\
\hline
\end{tabular}

The application of several types of pigments on a complex, interlinked panel indicates that the panel was created in a relatively short period of time by a small group of people, using each a different type of black crayon.

\subsubsection{Evidence of the contemporaneous work of at least two artists on one ensemble}

The case of two overlapping monothematic groups, Horses 84 and 85 and Mammoths 81 and 86, was chosen to demonstrate the complexity of the interpretation of the combined results of data from stylistic, superimposition, and chemical studies (Fig. 10). The graphic superimposition of the figures suggests the following timeline for their creation: Horse 84 was drawn first, followed by Mammoth 86, Horse 85 and finally Mammoth 81 . According to these observations, the two monothematic pairs do not in fact belong together and seem to have been drawn independently. By contrast, the chemical analysis showed chemical differences between the pairs of mammoths and the pairs of horses, but the same chemical composition within the pairs: the two horses belong to the high $\mathrm{BaO}$ group whereas the two mammoths fall into the intermediate $\mathrm{BaO}$ group. Two different raw materials seem to have been used in alternation to draw two different pairs of animals.

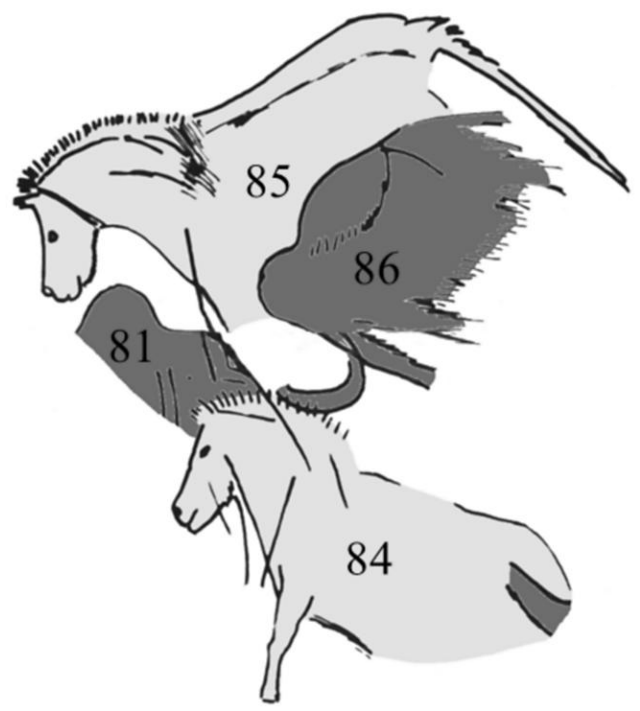

(single column fitting image)

Fig. 10: A detail of the Great Ceiling with two monothematic pairs, Horses 84 and 85, belonging to the high $\mathrm{BaO}$ group (light-gray) and Mammoths 81 and 86 , belonging to the intermediate $\mathrm{BaO}$ group (dark-gray).

\section{Conclusion}

In addition to the superimposition and stylistic studies conducted on all figures of the Great Ceiling non-invasive, in situ chemical analyses were conducted on 44 out of the 65 animal representations to determine the chemical compositions of the pigments used. This study makes the Great Ceiling the most extensively-studied Palaeolithic panel of artwork in the world in terms of chemical analysis. Three different pigment groups were identified, indicating the use of at least three different types of crayon in the creation of this complex panel. The holistic approach combining results from stylistic, superimposition, and chemical studies of the figures revealed an absence of overall unity in the Great Ceiling decoration but allowed for the definition of several coherent subgroups in the panel. The new chemical classifications support a rereading of several drawings and sets of figures, providing crucial new insights to refine the organization of subsets or sequences of action in the creation of the drawings. Furthermore, the alternating use of different crayons in the creation of more or less complex compositions was revealed. As the style of the figures is relatively homogeneous, this reinforces the idea that a very small 
team of artists probably created the Great Ceiling in a relatively short time, despite the apparent absence of a general structure. This conclusion is in line with observations made on the panels of drawings in other parts of the cave. The Ten Mammoths Frieze, in particular, forms a very structured and symmetric panel that can be regarded as a subset of the Great Ceiling. It is a significant example of a coherent panel drawn with one type of BaO-bearing $\mathrm{Mn}$ oxide pigment (intermediate $\mathrm{BaO}$ group) that was also found on the Great Ceiling. The question of whether the Ten Mammoths Frieze is contemporary with the figures on the Great Ceiling remains unresolved, although the two are consistent in terms of style and the pigments used. Still, our study demonstrates the value combined approaches to the non-invasive in situ analysis of prehistoric rock art in providing new organizational and chronological insights into sequences of creation in the absence of possibilities for absolute dating.

ACKNOWLEDGEMENTS. The authors acknowledge the support of LAMS in providing the portable XRF spectrometer as well as the Region Ile de France, which provided financial support through the DIM Analytics program. The "Commission Interrégionale de la Recherche Archéologique du Sud-Ouest" (CIRA), "Service régionale de l'Archéologie" (SRA) and DRAC Aquitaine are acknowledged for their financial support to our "opération archéologique" since 2014. The following colleagues are thanked through their support in providing access Rouffignac Cave and precious help during measurement: Jean and Marie-Odile Plassard and Frédéric Goursolle. Claire Heckel, $\mathrm{PhD}$, is thanked for the revision of the English language. Finally, the authors would like to thank the reviewers for their detailed valuable comments.

\section{Appendix A. Supplementary data}

Supplementary data to this article can be found online at http://doi.org/10.1016/j.jasrep.2019.102006.

\section{References}

Arias, P., Laval, E., Menu, M., González, S.C., Ontañón, R., 2011. Les colorants dans l'art pariétal et mobilier paléolithique de La Garma (Cantabrie, Espagne). l'Anthropologie 115, 425-445.

Aujoulat, N., 2004. Lascaux. Le geste, l’espace et le temps. Édition du Seuil, Paris, p. 274.

Ballet, O., Bocquet, A., Bouchez, R., Coey, J.M.D., Cornu, A., 1979. Étude technique des poudres colorées de Lascaux. Lascaux Inconnu, XIIème Supplément à Gallia Préhistoire. Éditions Leroi-Gourhan A \& Allain J (CNRS, Paris), 171-174.

Barrière, Cl., 1980. Le Grand Plafond de Rouffignac. Bull Soc Française Préhistoire, 77(9), 269-276.

Barrière, Cl, 1982. L'art pariétal de Rouffignac. Picard, Fondation Singer-Polignac, Paris, p. 208.

Beck, L., Rousselière, H., Castaing, J., Duran, A., Lebon, M., Lahlil, S., Plassard, F., 2012. Analyse in situ des dessins préhistoriques de la grotte de Rouffignac par fluorescence X et diffraction X portable. ArchéoSciences 36, 139-152.

Beck, L., Rousselière, H., Castaing, J., Duran, A., Lebon, M., Moignard, B., Plassard, F., 2014. First use of portable system coupling X-ray diffraction and X-ray fluorescence for in situ analysis of prehistoric rock art. Talanta 129, 459-464.

Bourdier, C., 2010. Paléogéographie symbolique au Magdalénien moyen. Apport de l'étude des productions graphiques pariétales des abris occupés et sculptés de l'Ouest français (Roc-aux-Sorciers, Chaire-à-Calvin, Reverdit, Cap-Blanc). Thèse de doctorat de l'Université Bordeaux 1, p. 407.

Breuil, H., 1952. Quatre cent siècles d'art pariétal. Édition du Centre d'études et de documentation préhistoriques, Montignac, Dordogne, p. 419.

Cabrera-Garrido, J.M., 1978. Les Matériaux des peintures de la grotte d'Altamira. Actes de la $5^{\mathrm{e}}$ réunion triennale de 1'ICOM, Zagreb, 1-9. Chalmin, E., Menu, M., Vignaud, C., 2003. Analysis of rock art paintings and technology of Palaeolithic painters. Meas. Sci. Technol. 14 $1590-1597$.

Chalmin, E., Huntley, J., 2017. Characterizing Rock Art Pigments. The Oxford Handbook of the Archaeology and Anthropology of Rock Art. Edited by Bruno David and Ian J. McNiven. On line.

Chippindale C., Taçon P.S.C., 1998. The many ways of dating Arnhem Land rock-art, north Australia. The archaeology of rock art, 90111

Clottes, J., Menu, M., Walter, P., 1990. La préparation des peintures magdaléniennes des cavernes ariégeoises. Bulletin de la Société préhistorique française 87 (N.6), 170-192.

Dayet, L., 2013. Matériaux, transformations et fonctions de l'ocre au Middle Stone Age : Le cas de Diepkloof Rock Shelter dans le contexte de l'Afrique australe. Thèse de Doctorat de l'Université Bordeaux 3, p. 420.

De Sanoit, J., Chambellan, D., Plassard, F., 2005. Caractérisation in situ du pigment noir de quelques oeuvres pariétales de la Grotte de Rouffignac à l'aise d'un système portable d'analyse par fluorescence X (XRF). ArchéoSciences 29, 61-68.

Fritz, C. (Dir.), 2017. L'art de la Préhistoire. Citadelles et Mazenod, p. 584.

Gay, M., Alfeld, M., Menu, M., Laval, E., Arias, P., Ontañón, R., Reiche, I., 2015. Palaeolithic paint palettes used at La Garma Cave (Cantabria, Spain) investigated by means of combined in situ and synchrotron X-ray analytical methods. J. Anal. At. Spectrom. 30, 767776 .

Gay, M., Müller, K., Plassard, F., Reiche, I., 2016. Efficient quantification procedures for data evaluation of portable X-ray fluorescence Potential improvements for Palaeolithic cave art knowledge. J Archaeol Sci: Reports. 10, 878-886.

Grazioso, P., 1956. Analyses chimiques des peintures de la grotte de Rouffignac. La Nature, 3258, décembre 1956, Dunod, p. 469.

Harris, E., Gunn, R.G., 2017. The use of Harris Matrices in rock art research. in: The Oxford Handbook of the Archaeology and Anthropology of Rock Art. Bruno David and Ian J. McNiven (eds.). On line, printed version: Oxford University Press 2018, New York, USA, 911-916.

Huntley, J., 2012. Taphonomy or paint recipe? In situ portable X-ray fluorescence analysis of two anthropomorphic motifs from the south Woronora Plateau. Australian Archaeology, 75, 78-94.

Lahlil, S., Lebon, M., Beck, L., Rousselière, H., Vignaud, C., Reiche, I., Menu, M., Paillet, P., Plassard, F., 2012. The first in situ microRaman spectroscopic analysis of prehistoric cave art of Rouffignac St-Cernin, France. J. Raman Spectrosc. 43, 1637-1643.

Leroi-Gourhan, A., 1965. Préhistoire de l'art occidental. Éditions Mazenod, Paris. 
Lorblanchet, M., 1994. La datation de l'art pariétal paléolithique. Bulletin de la société des Etudes du Lot. CXV(3), 161-182.

Lorblanchet, M., 2010. Art pariétal. Grottes ornées du Quercy. Édition du Rouergue, p. 445.

Mauran, G., Lebon, M., Détroit, F., Caron, B., Nankela, A., Pleurdeau, D., Bahain, J.-J., 2019. First in situ pXRF analyses of rock paintings in Erongo, Namibia: results, current limits, and prospects. Archaeological and Anthropological Sciences, 1-23.

Menu, M., Walter, P., 1992. Prehistoric cave painting PIXE analysis for the identification of paint "pots". Nucl. Instrum. Methods Phys. Res. 64, 547-552.

Nougier, L.-R., Robert, R., 1957. Rouffignac ou la Guerre des mammouths. Éditions La Table Ronde, Paris, p. 311.

Nougier, L.-R., Robert, R., 1959. Rouffignac. I - Galerie Henri Breuil et Grand Plafond. Éditions Sansoni, Florence, p. 79.

Nuevo, M.J., Martín, S.A., Oliveira, C., Oliveira de, J., 2012. In situ energy dispersive X-ray fluorescence analysis of rock art pigments from the 'Abrigo dos Gaivões' and Igreja dos Mouros' caves (Portugal). X-Ray Spectrom. 41, 1-5.

Olivares, M., Castro, K., Corchón, M.-S., Gárate, D., Murelaga, X., Sarmiento, A., Etxebarria, N., 2013. Non-invasive portable instrumentation to study Palaeolithic rock paintings: the case of La Peña Cave in San Roman de Candamo (Asturias, Spain). J. Archaeol. Sci. 40, 1354-1360.

Plassard, J., 1999. Rouffignac, le sanctuaire des mammouths. Éditions du Seuil, Paris, p. 99.

Plassard, F., 2005. Les grottes ornées de Combarelles, Font-de-Gaume, Bernifal et Rouffignac. Contexte archéologique, thèmes et style des représentations. Thèse de Doctorat de l'Université Bordeaux 1, p. 413.

Plassard, F., Plassard, J., 2016. Le grand plafond de Rouffignac. De nouveaux indices sur l'organisation des images. Paléo Hors-série, Hommage à Norbert Aujoulat, 143-151.

Quiles, A., Valladas, H., Bocherens, H., Delqué-Kolic, E., Kaltnecker, E., van der Plicht, J., Delannoy, J.-J., Feruglio, V., Fritz, C., Monney, J., Philippe, M., Tosello, G., Clottes, J., Geneste, J.-M., 2016. A high-precision chronological model for the decorated Upper Paleolithic cave of Chauvet-Pont d'Arc, Ardèche, France. Proc Natl Acad Sci USA, 113(7), 4670-4675.

Roldán, C., Murcia-Mascarós, S., Ferrero, J., Villaverde, V., López, E., Domingo, I., Martínez, R., Guillem, P.M., 2010. Application of field portable EDXRF spectrometry to analysis of pigments of Levantine rock art. X-Ray Spectrom, 39, 243-250.

Salomon, H., 2009. Les matières colorantes au début du Paléolithique Supérieur: Sources, transformations et fonctions. Thèse de Doctorat de l'Université Bordeaux 1, p. 432.

Sepulveda, M., Gutierrez, S., Carcamo, J., Oyaneder, A., Valenzuela, D., Montt, I., Santoro, C. M., 2015. In situ X-Ray fluorescence analysis of rock art paintings along the coast and valleys of the Atacama desert, Northern Chile. Journal of the Chilean Chemical Society 60, 2822-2826.

Solé, V.A., Papillon, E., Cotte, M., Walter, P., Susini, J., 2007. A multiplatform code for the analysis of energy-dispersive X-ray fluorescence spectra. Spectrochim. Acta B 62, 63-68.

Tosello, G., 2003. Pierres gravées du Périgord Magdalénien. Art, symboles, territoires. Paris, CNRS éditions (Suppléments à Gallia Préhistoire, 36), p. 590.

Valladas, H., Clottes, J., 2003. Style, Chauvet and radiocarbon. Antiquity, 77(295), 142-145.

Vandiver, P., 1983. Palaeolithic pigments and processing. Master Science Thesis of the department of material science and engineering, MIT University (USA).

Vignaud, C., Salomon, H., Chalmin, E., Geneste, J.-M., Menu, M., 2006. Le groupe des "bisons adossés" de Lascaux. Etude de la technique de l'artiste par analyse des pigments. l'Anthropologie 110, 482-499.

Wallis, L.A., Huntley, J., Marsh, M., Watchman, A., Ewen, A., Strano, A., 2016. PXRF analysis of a yellow ochre quarry and rock art motifs in the Central Pilbara. Journal of the Anthropological Society of South Australia, 40, 134-155. 